\title{
Molecular study on copper-mediated tumor proteasome inhibition and cell death
}

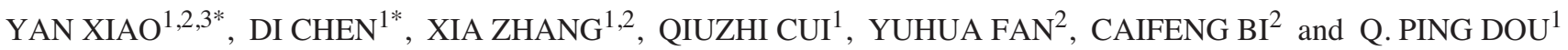 \\ ${ }^{1}$ The Prevention Program, Barbara Ann Karmanos Cancer Institute, and Department of Pathology, School of Medicine, \\ Wayne State University, Detroit, MI 48201, USA; ${ }^{2}$ Key Laboratory of Marine Chemistry Engineering and Technology, \\ Ministry of Education, College of Chemistry and Chemical Engineering, Ocean University of China; ${ }^{3}$ Qingdao Institute \\ of Bioenergy and Bioprocess Technology, Chinese Academy of Sciences, Qingdao 266101, P.R. China
}

Received January 13, 2010; Accepted March 4, 2010

\section{DOI: 10.3892/ijo_00000655}

\begin{abstract}
The metal ion copper is a cofactor essential for maintaining normal biological and physical functions in human beings. High copper levels have been found in variety of tumor tissues and are involved in tumor angiogenesis processes. The ubiquitin-proteasome system plays an important role in cell growth and apoptosis and has been shown as a novel target for cancer therapy. We previously reported that some organic copper complexes can inhibit the proteasomal chymotrypsin-like activity and induce apoptosis in human cancer cells and xenograft models. In the current study, we investigated the effect of oxidation status of copper, $\mathrm{Cu}(\mathrm{I})$ or $\mathrm{Cu}(\mathrm{II})$, on inhibition of proteasome activity, induction of apoptosis, and induction of reactive oxygen species (ROS) in human cancer cells. We report four major findings here: i) both $\mathrm{Cu}(\mathrm{I})$ and $\mathrm{Cu}$ (II) could inhibit the chymotrypsin-like activity of purified $20 \mathrm{~S}$ proteasome, but $\mathrm{Cu}(\mathrm{I})$ was more potent than $\mathrm{Cu}(\mathrm{II})$, ii) purified $20 \mathrm{~S}$ proteasome protein was able to reduce $\mathrm{Cu}$ (II) to $\mathrm{Cu}(\mathrm{I})$, suggesting that $\mathrm{Cu}(\mathrm{I})$ is the oxidation status of copper that directly reacts with the proteasome, iii) when complexed with the copper ligand neocuproine, $\mathrm{Cu}(\mathrm{I})$ showed higher ability to induce $\mathrm{ROS}$ production in cancer cells, compared with $\mathrm{Cu}(\mathrm{II})$, iv) addition of a ROS scavenger in the cancer cell culture-blocked copperinduced ROS generation, but did not overcome coppermediated proteasome-inhibitory and cell death-inducing events, demonstrating the ROS-independent proteasomeinhibitory property of copper complexes.
\end{abstract}

Correspondence to: Dr Q. Ping Dou, The Prevention Program, Barbara Ann Karmanos Cancer Institute and Department of Pathology, School of Medicine, Wayne State University, 540.1 HWCRC, 4100 John R. Road, Detroit, MI 48201, USA

E-mail: doup@karmanos.org

${ }^{*}$ Contributed equally

Key words: copper, oxidation status, proteasome inhibition, apoptosis, ROS

\section{Introduction}

Copper $(\mathrm{Cu})$ is an essential trace metal for mammalians and human beings $(1,2)$. One of the important physiological functions of $\mathrm{Cu}$ is to serve as a cofactor in a process of formation of new blood vessels, termed as angiogenesis $(3,4)$. Tumor growth invasion and metastasis all depend on angiogenesis. It has been shown that tumors can not grow $>1-2 \mathrm{~mm}^{3}$ without forming new blood vessels (5). High tissue levels of copper have been found in many types of human cancers, including breast, prostate, colon, lung and brain (5-9). The ubiquitinproteasome-dependent degradation system plays an important regulatory role in processes of cell growth and apoptosis. Development of proteasome inhibitors as novel anti-cancer agents is currently under intensive investigation. Previously we found that certain organic copper ligands can react with cupric copper $\left(\mathrm{CuCl}_{2}\right)$ and form complexes. These complexes are potent proteasome inhibitors and can induce apoptotic cell death in cancer cells in vitro and in vivo (10-13). In the current study, we further investigated which oxidation states of copper, $\mathrm{Cu}(\mathrm{I})$ or $\mathrm{Cu}(\mathrm{II})$, serve as a proteasome inhibitor and an apoptosis inducer in cancer cells. Under cell-free conditions, we found that purified $20 \mathrm{~S}$ proteasome could reduce $\mathrm{Cu}$ (II) to $\mathrm{Cu}$ (I) and that both $\mathrm{Cu}$ (I) and $\mathrm{Cu}$ (II) could inhibit the activity of a purified $20 \mathrm{~S}$ proteasome, but $\mathrm{Cu}(\mathrm{I})$ is more potent that $\mathrm{Cu}(\mathrm{II})$. Data from cell culture studies showed that when $\mathrm{Cu}$ (I) or $\mathrm{Cu}(\mathrm{II})$ was mixed with neocuproine (NC), a copper-binding compound, both copper mixtures could inhibit proteasome activity and induce apoptosis in tumor cells, and $\mathrm{Cu}(\mathrm{I})$ mixture was slightly more potent. We also found that the $\mathrm{Cu}(\mathrm{I})$ mixture was a strong ROS inducer and that a ROS scavenger could block the ROS generation produced by $\mathrm{Cu}(\mathrm{I})$ mixture but could not overcome its proteasomeinhibitory activity. Our data suggest that the inhibition of proteasome activity by copper complexes might be mainly through the direct binding of copper to the proteasome, and that oxidative stress or ROS generation may be only partially responsible for the copper-induced tumor cell death.

\section{Materials and methods}

Reagents and antibodies. Purified rabbit 20S proteasome, fluorogenic peptide substrate was obtained from Calbiochem 
(San Diego, CA). BCS (bathocuproinedisulfonic acid disodium salt), hydroxide peroxide, NC (neocuproine, 2,9dimethyl-1,10-phenanthroline), copper chloride and $\mathrm{AH}$ (ascorbic acid) were obtained from Sigma. RPMI-1640, DMEM/F-12, penicillin and streptomycin were purchased from Invitrogen. Mouse monoclonal antibody against human poly(ADP-ribose) polymerase (PARP) was purchased from BD Biosciences Pharmingen (San Diego, CA). Mouse monoclonal antibody against ubiquitin (P4D1), goat polyclonal antibodies against actin ( $\mathrm{C}-11)$ and $\mathrm{I \kappa} \mathrm{B}-\alpha(\mathrm{C} 15)$, and secondary antibodies were from Santa Cruz Biotechnology, Inc. The antibody against proteasomal $B 5$ subunit was from BIOMOL International (Plymouth Meeting, PA, USA). The Image-iT ${ }^{\mathrm{TM}}$ live green ROS detection kit was purchased from Molecular Probes (Eugene, OR, USA).

Cell cultures and whole cell extract preparation. Human Jurkat $\mathrm{T}$ cells were cultured in RPMI-1640 medium, supplemented with $10 \%$ fetal bovine serum, $100 \mathrm{U} / \mathrm{ml}$ penicillin and $100 \mu \mathrm{g} / \mathrm{ml}$ streptomycin. MDA-MB-231 human breast cancer cells were obtained from American Type Culture Collection (Manassas, VA) and grown in DMEM/F-12 supplemented with $10 \%$ fetal bovine serum, $100 \mathrm{U} / \mathrm{ml}$ penicillin and $100 \mu \mathrm{g} / \mathrm{ml}$ streptomycin. All cells were maintained at $37^{\circ} \mathrm{C}$ and $5 \% \mathrm{CO}_{2}$. A whole cell extract was prepared as described previously (10).

Color change and precipitate formation reactions. $\mathrm{NC}, \mathrm{AH}$, $\mathrm{CuCl}$ and $\mathrm{CuCl}_{2}$ were dissolved in DMSO to a final concentration of $50 \mathrm{mM}$. $\mathrm{CuCl}$ or $\mathrm{CuCl}_{2}$ was then mixed with $\mathrm{NC}$ or $\mathrm{AH}$ in a 1:4 ratio or with $\mathrm{NC}$ and $\mathrm{AH}$ in a 1:4:4 ratio, followed by examination of color change, as an indicator of complex formation.

Trypan blue exclusion assay. The trypan blue dye exclusion assay was performed by mixing $20 \mu 1$ of $0.4 \%$ trypan blue dye and $20 \mu \mathrm{l}$ of Jurket $\mathrm{T}$ cells treated with different concentration of NC-copper complexes before injecting into a hemocytometer and counting. The number of cells that absorbed the dye and those that exclude the dye were counted, from which the percentage of non-viable cell number to total cell number was calculated.

Inhibition of the proteasomal chymotrypsin-like activity in cell extracts. Whole cell extracts $(5 \mu \mathrm{g})$ of treated MDA-MB231 cells were incubated for $2 \mathrm{~h}$ at $37^{\circ} \mathrm{C}$ in $100 \mu 1$ of assay buffer (50 mM Tris-HCl, pH 7.5) with $10 \mu \mathrm{mol} / \mathrm{l}$ fluorogenic peptide substrate Suc-LLVY-AMC for the proteasomal chymotrypsin-like activity. After incubation, production of hydrolyzed AMC groups was measured with a Wallac Victor 3 Multiabel Counter with an excitation filter of $365 \mathrm{~nm}$ and emission filter of $460 \mathrm{~nm}$. Changes in fluorescence were calculated against DMSO-treated control.

Measurement of the reduction of $\mathrm{Cu}(\mathrm{II})$ to $\mathrm{Cu}(\mathrm{I})$. Reduction of $\mathrm{Cu}$ (II) to $\mathrm{Cu}(\mathrm{I})$ generation was determined by using BCS, according to the published method (14), based on the specific absorption of $\mathrm{Cu}(\mathrm{I})$-BCS complex at $480 \mathrm{~nm}$ wavelength. Purified 20S proteasome (35 ng) was mixed with $\mathrm{CuCl}_{2}$ or $\mathrm{CuCl}$ and $100 \mu \mathrm{M}$ of BCS in PBS, pH 7.3, and then incubated at $37^{\circ} \mathrm{C}$ for $2 \mathrm{~h}$. The absorption of each sample was measured by a spectrophotometer at $480 \mathrm{~nm}$ wavelength.

Western blot analysis. The cell extracts were separated by SDS-PAGE and transferred to a nitrocellulose membrane. Western blot analysis was done using indicated specific antibodies, following by visualization with the enhanced chemiluminescence reagent.

Visualization of ROS in live tumor cells. The Image-iT live green ROS detection kit was used to visualize ROS in live MDA-MB-231 cells. Carboxy- $\mathrm{H}_{2}$ DCFDA [5-(and-6)carboxy-2',7'-dichlorodihydrofluorescein diacetate] is a cellpermeable non-fluorescent indicator reagent. When the carboxy- $\mathrm{H}_{2}$ DCFDA permeates into live cells, it can be deacetylated by intracellular esterases and oxidized by cellular ROS, and then it is converted to the fluorescent form DCF by emitting bright green color. Tert-butyl hydroperoxide (TBHP), a ROS inducer, was used as positive control. A Zeiss Axiovert 25 microscope was used for capturing images of oxidized fluorescein (green fluorescence), nuclei (blue fluorescence, Hoechst 33342) and cellular morphology.

\section{Results}

Both $\mathrm{NC}-\mathrm{CuCl}$ and $\mathrm{NC}-\mathrm{CuCl} \mathrm{Cl}_{2}$ were able to inhibit proteasome activity and induce cell death in human leukemia Jurkat T cells. Previously we found that some copper ligands could react with cupric copper chloride $\left(\mathrm{CuCl}_{2}\right)$ and formed organic copper complexes (13). These complexes were able to inhibit the cellular proteasome activity and induce apoptotic cell death in cancer cells in vitro and in vivo $(10,12,13,15)$. In the current study we examined whether cuprous copper $(\mathrm{CuCl})$ when mixed with a copper ligand could play the similar biological role as $\mathrm{CuCl}_{2}$ in cancer cells. Because of the unstable nature of $\mathrm{Cu}(\mathrm{I})$ species, comparison of effect of oxidation status of inorganic copper in cells remains difficult. Therefore, we used neocuproine (NC), a copper ligand to form organic copper complexes with $\mathrm{CuCl}$ or $\mathrm{CuCl}_{2}$, respectively in the current experiment. It has been reported that $\mathrm{NC}$ can bind with inorganic copper, especially cuprous copper, to form a complex and present color changes from no color to light orange (16). To test the reaction of $\mathrm{NC}$ with cuprous and cupric copper chloride, we mixed $\mathrm{NC}$ and $\mathrm{CuCl}$ or $\mathrm{CuCl}_{2}$ solution in a 4:1 molar ratio in DMSO. Slight color change was observed in $\mathrm{NC}-\mathrm{CuCl}$ mixture (data not shown), indicating that a chemical reaction had occurred. $\mathrm{CuCl}$ is not stable and is easily oxidized and converted to $\mathrm{CuCl}_{2}$. To protect $\mathrm{CuCl}$ from being oxidized to $\mathrm{CuCl}_{2}$, we added ascorbic acid $(\mathrm{AH})$ as a reducer in a 1:4 molar ratio. (17). When $\mathrm{NC}$ was mixed with $\mathrm{AH}$ and $\mathrm{CuCl}(\mathrm{NC}-\mathrm{AH}-\mathrm{CuCl})$ or with $\mathrm{AH}$ and $\mathrm{CuCl}_{2}\left(\mathrm{NC}-\mathrm{AH}-\mathrm{CuCl}_{2}\right)$, dramatic color changes were observed. There is no color change observed in the mixtures of $\mathrm{NC}-\mathrm{AH}, \mathrm{AH}-\mathrm{CuCl}$ or $\mathrm{AH}-\mathrm{CuCl}_{2}$ (data not shown). We then used the mixtures of $\mathrm{NC}-\mathrm{CuCl}-\mathrm{AH}$ ( $\mathrm{AH}$ was always added in $\mathrm{NC}-\mathrm{CuCl}$ complex if not mentioned) and $\mathrm{NC}-\mathrm{CuCl}_{2}$ for further investigation using cancer cell culture.

We hypothesized that $\mathrm{NC}-\mathrm{CuCl}$ and $\mathrm{NC}-\mathrm{CuCl}_{2}$ may have similar biological effects on proteasome inhibition and 
apoptosis induction in cancer cells. First of all, we tested whether these complexes were capable of inhibiting the proteasome activity in intact tumor cells. Human leukemia Jurkat T cells were treated with $\mathrm{NC}-\mathrm{CuCl}_{2}$ or $\mathrm{NC}-\mathrm{CuCl}-\mathrm{AH}$, with $\mathrm{NC}, \mathrm{AH}, \mathrm{CuCl}_{2}, \mathrm{CuCl}$ alone or DMSO as controls at indicated concentrations. After $3 \mathrm{~h}$ of treatment, cells were incubated with fluorogenic peptide substrate for additional $2 \mathrm{~h}$ and then proteasome chymotrypsin (CT)-like activity was measured. The results showed that both $\mathrm{NC}-\mathrm{CuCl}_{2}$ and $\mathrm{NC}-$ $\mathrm{CuCl}-\mathrm{AH}$ significantly inhibited the proteasome activity in intact Jurkat $\mathrm{T}$ cells, as indicated by decreased levels of the proteasomal chymotrypsin-like activity (Fig. 1A). Moreover, the $\mathrm{NC}-\mathrm{CuCl}-\mathrm{AH}$ was more potent than that of $\mathrm{NC}-\mathrm{CuCl}_{2}$, measured as 25 vs. $14 \%$ inhibition at $1 \mu \mathrm{M}$ and 60 vs. $49 \%$ inhibition at $10 \mu \mathrm{M}$ concentrations of NC-CuCl-AH and NC$\mathrm{CuCl}_{2}$, respectively (Fig. 1A). In contrast, the treatments with $\mathrm{NC}, \mathrm{AH}, \mathrm{CuCl}_{2}$ or $\mathrm{CuCl}$ alone had no effects on proteasome activity (Fig. 1A).

Cytotoxicity against Jurkat $\mathrm{T}$ cells was then measured by trypan blue dye exclusion assay. Jurkat $\mathrm{T}$ cells were treated with different concentrations of $\mathrm{NC}-\mathrm{CuCl}-\mathrm{AH}$ or $\mathrm{NC}-\mathrm{CuCl}_{2}$ for 5 or $22 \mathrm{~h}$ (Fig. 1B and C). The results showed that both copper complexes could induce cell death. Compared with $\mathrm{NC}-\mathrm{CuCl}_{2}, \mathrm{NC}-\mathrm{CuCl}-\mathrm{AH}$ was more potent at all concentrations tested after $5 \mathrm{~h}$ of treatment, for example, $40 \%$ cell death by $\mathrm{NC}-\mathrm{CuCl}-\mathrm{AH}$ at $10 \mu \mathrm{M}$ compared to $30 \%$ cell death by $\mathrm{NC}^{-\mathrm{CuCl}_{2}}$ at the same concentration (Fig. 1B). After $22 \mathrm{~h}$ of treatment, all the cells treated with $1 \mu \mathrm{M} \mathrm{NC}-\mathrm{CuCl}-\mathrm{AH}$ were dead. Treatment with $\mathrm{NC}-\mathrm{CuCl}_{2}$ mixture at the same concentration resulted in only $45 \%$ cell death (Fig. 1C).

Treatment with $\mathrm{NC}-\mathrm{CuCl} \mathrm{Cl}_{2}$ and $\mathrm{NC}-\mathrm{CuCl}-\mathrm{AH}$ results in proteasome inhibition and apoptotic cell death in breast cancer cells. We then examined the effects of $\mathrm{NC}-\mathrm{CuCl}_{2}$ and $\mathrm{NC}-\mathrm{CuCl}-\mathrm{AH}$ on solid tumor cells. Human breast cancer MDA-MB-231 cells were treated with $\mathrm{NC}-\mathrm{CuCl}_{2}$, or $\mathrm{NC}-\mathrm{CuCl}-$ $\mathrm{AH}$ or DMSO at indicated concentrations for $19 \mathrm{~h}$ (Fig. 2). After each treatment, proteins were extracted and used for measurement of proteasome activity by decreasing levels of cellular proteasomal chymotrypsin-like activity and accumulation of ubiquitinated proteins and proteasome target protein IкB- $\alpha$.

We found that both complexes could inhibit proteasomal chymotrypsin-like activity and that $\mathrm{NC}-\mathrm{CuCl}-\mathrm{AH}$ was more potent than $\mathrm{NC}-\mathrm{CuCl}_{2}$ at all concentrations tested (Fig. 2A). Also, levels of ubiquitinated proteins were accumulated by treatment with both complexes at all concentrations tested (Fig. 2B). The ubiquitinated form $(56 \mathrm{kDa})$ of IкB- $\alpha$ protein was observed mainly in the cells treated with $1 \mu \mathrm{M}$ of $\mathrm{NC}$ $\mathrm{CuCl}_{2}$ or $\mathrm{NC}-\mathrm{CuCl}-\mathrm{AH}$ (Fig. 2B).

It has been reported that inhibition of proteasome chymotrypsin-like activity in cancer cells is associated with apoptosis induction $(18,19)$. To investigate whether the complexes have apoptosis-inducing activity, morphologic changes and apoptosis-associated PARP cleavage were studied. Cellular apoptotic morphology changes (shrunken and blebbing) were observed starting at $0.5 \mu \mathrm{M}$ and were more severe at $1 \mu \mathrm{M}$ treatment with both complexes (Fig. 2C). Consistent with apoptosis induction, PARP cleavage fragment
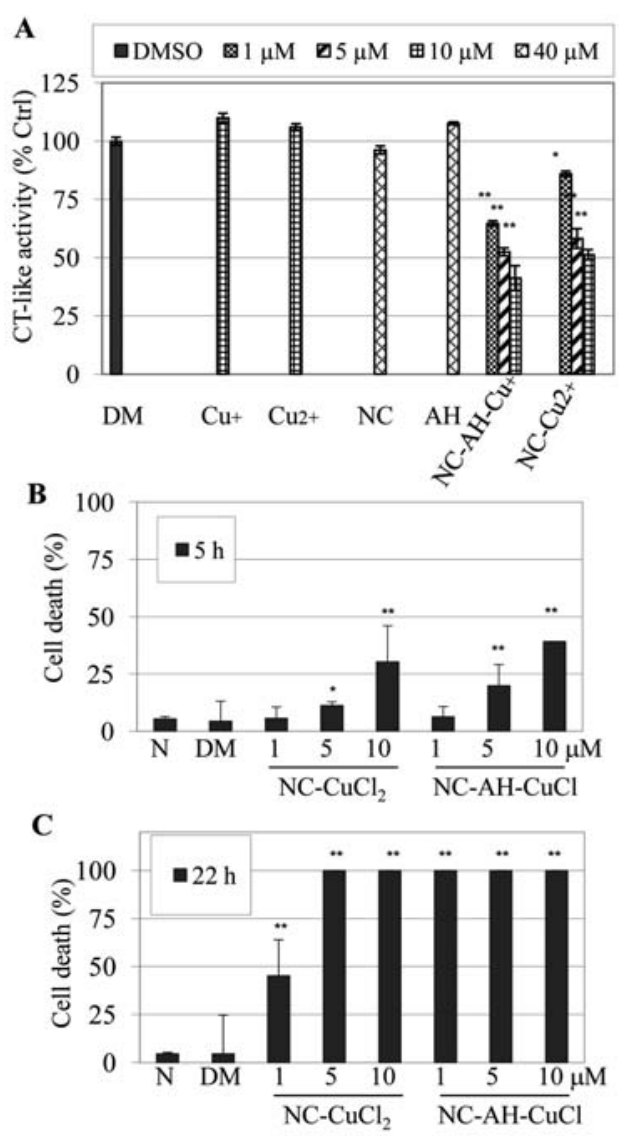

Figure 1. Both of $\mathrm{NC}-\mathrm{CuCl}$ and $\mathrm{NC}-\mathrm{CuCl}_{2}$ mixtures could inhibit proteasome activity and reduce cell death in Jurkat T cells. (A) Human leukemia Jurkat $\mathrm{T}$ cells were treated with indicated doses of $\mathrm{CuCl}\left(\mathrm{Cu}^{+}\right), \mathrm{CuCl}_{2}\left(\mathrm{Cu}^{2+}\right), \mathrm{NC}$, $\mathrm{AH}$ alone or $\mathrm{NC}$ mixtures with $\mathrm{CuCl}$ or $\mathrm{CuCl}_{2}$ for $5 \mathrm{~h}$, followed by measurement of proteasome chymotrypsin (CT)-like activity. (B and $\mathrm{C}$ ) Jurkat $\mathrm{T}$ cells were treated with indicated concentrations of $\mathrm{NC}$ and copper mixtures for 5 (B) or $22 \mathrm{~h}(\mathrm{C})$, followed by trypan blue dye exclusion assay. Treatment with DMSO (DM) or no-treatment $(\mathrm{N})$ was used as controls. ${ }^{*} \mathrm{P}<0.05,{ }^{* *} \mathrm{P}<0.01$, bars, $\mathrm{SD}$, mean of three experiments.

p85 was observed in the cells treated with both complexes at 0.5 and $1 \mu \mathrm{M}$ (Fig. 2B). Both complexes have similar activity in inducing apoptosis.

Purified 20S proteasome is able to reduce $\mathrm{Cu}(\mathrm{II})$ to $\mathrm{Cu}(\mathrm{I})$ and both $\mathrm{CuCl}$ and $\mathrm{CuCl}_{2}$ can inhibit the activity of purified 20S proteasome. So far, all obtained data above have shown that both $\mathrm{NC}-\mathrm{CuCl}$ and $\mathrm{NC}-\mathrm{CuCl}_{2}$ have similar effects on proteasome inhibition and cell death induction and $\mathrm{NC}-\mathrm{CuCl}$ is slightly more potent than $\mathrm{NC}-\mathrm{CuCl}_{2}$. However, it is still unclear what oxidation status of copper interacts with the proteasome complex. Some transition metal ions, mainly iron and copper, at reducing conditions, are able to catalyze the formation of hydroxyl radicals by Fenton-type reactions. If the proteasome inhibition caused by $\mathrm{Cu}(\mathrm{II})$ occurs via Fenton Reactions, we would expect that $20 \mathrm{~S}$ proteasome could reduce $\mathrm{Cu}(\mathrm{II})$ to $\mathrm{Cu}(\mathrm{I})$, and the hydroxyl radicals could repeatedly be formed by recycling $\mathrm{Cu}$ (II) back to $\mathrm{Cu}(\mathrm{I})$. Indeed, when we incubated a purified $20 \mathrm{~S}$ proteasome with cupric copper chloride at $37^{\circ} \mathrm{C}$ for $2 \mathrm{~h}$ in the presence of the $\mathrm{Cu}(\mathrm{I})$ indicator bathocuproinedisulfonic acid (BCS), we detected formation of a $\mathrm{Cu}(\mathrm{I})$ species, as indicated by the 

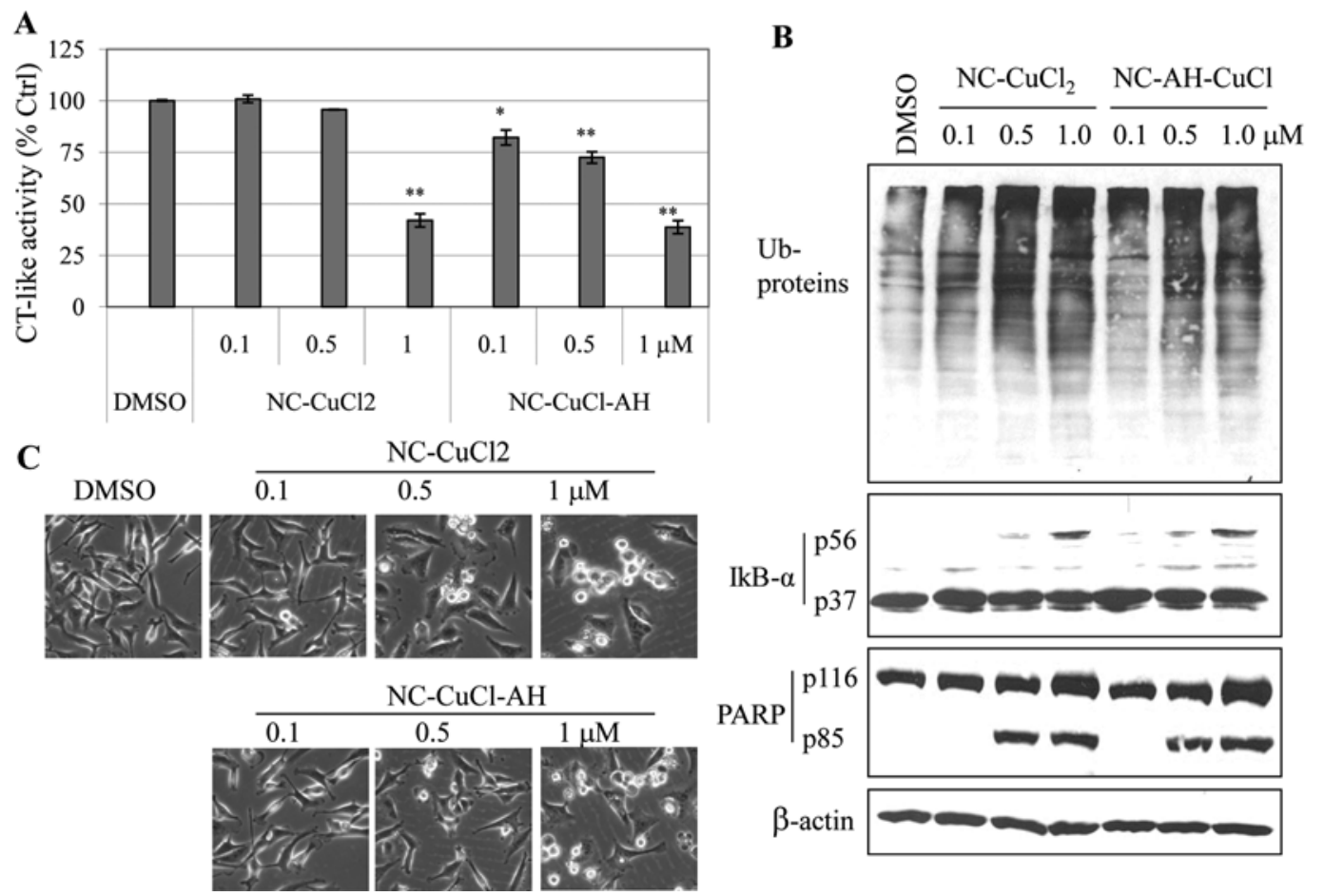

Figure 2. Proteasome-inhibitory and apoptosis-inducing effects of $\mathrm{NC}-\mathrm{CuCl}_{2}, \mathrm{NC}-\mathrm{AH}-\mathrm{CuCl}$ on breast cancer cells. MDA-MB-231 cells were treated with indicated concentrations of $\mathrm{NC}-\mathrm{CuCl}_{2}, \mathrm{NC}-\mathrm{AH}-\mathrm{CuCl}$ for $19 \mathrm{~h}$, followed by measurement of proteasome activity (A), Western blot analysis (B) and cellular morphological changes (magnification, x100) (C). DMSO (DM) was used as solvent control. ${ }^{*} \mathrm{P}<0.05,{ }^{* *} \mathrm{P}<0.01$, bars, SD, mean of three experiments.

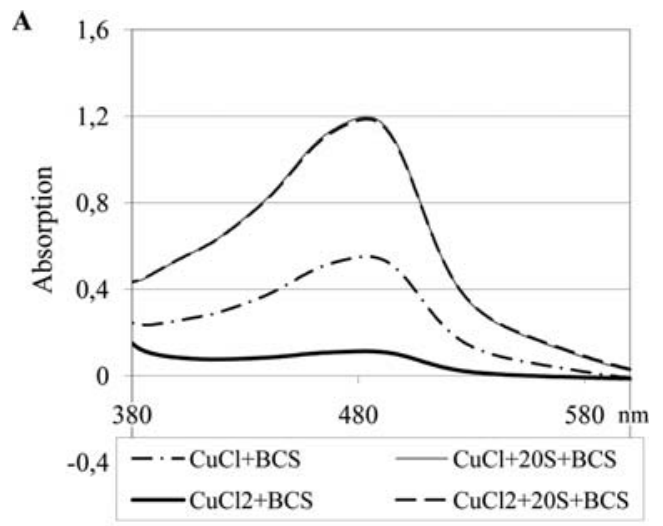

B

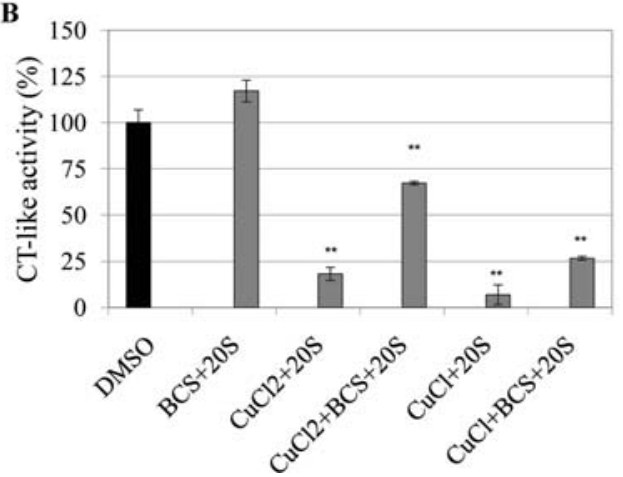

Figure 3. Purified 20S proteasome reduces $\mathrm{Cu}(\mathrm{II})$ to $\mathrm{Cu}(\mathrm{I})$. (A) $\mathrm{Cu}(\mathrm{I})$ chloride $(\mathrm{CuCl})(10 \mu \mathrm{M})$ or $\mathrm{Cu}(\mathrm{II})$ chloride $\left(\mathrm{CuCl}_{2}\right)$ was mixed with $\mathrm{Cu}(\mathrm{I})$ indicator BCS $(100 \mu \mathrm{M})$ with or without purified $20 \mathrm{~S}$ proteasome $(35 \mathrm{ng})$ and incubated at $37^{\circ} \mathrm{C}$ for $2 \mathrm{~h}$, followed by measuring absorption of each sample in a spectrophotometer. (B) The solutions in Fig. 3A were incubated with fluorogenic peptide substrate Suc-LLVY-AMC $(20 \mu \mathrm{M})$ for $1 \mathrm{~h}$ at $37^{\circ} \mathrm{C}$, followed by measuring the proteasome chymotrypsin (CT)-like activity. ${ }^{* *} \mathrm{P}<0.01$, bars, $\mathrm{SD}$, mean of three experiments. appearance of a peak with maximal absorbance at $480 \mathrm{~nm}$, a characteristic of the BCS-Cu(I) complex (Fig. 3A) (14). In contrast, after incubation of BCS with $\mathrm{Cu}(\mathrm{II})$ without purified $20 \mathrm{~S}$ proteasome, just a slight increase in absorbance at $480 \mathrm{~nm}$ was observed, and BCS and $\mathrm{Cu}(\mathrm{II})$ alone did not cause any increase in the absorbance at $480 \mathrm{~nm}$ (Fig. 3A). Those results clearly demonstrate that purified $20 \mathrm{~S}$ proteasome is able to reduce $\mathrm{Cu}$ (II) to $\mathrm{Cu}$ (I), further suggesting that $\mathrm{Cu}(\mathrm{I})$ could directly react with $20 \mathrm{~S}$ proteasome and consequently inhibit the proteasome activity. In order to measure the proteasome activity in the same experiment, the fluorogenic peptide substrate Suc-LLVY-AMC for proteasome was added to all the reaction mixtures above and incubated for $1 \mathrm{~h}$, followed by determination of released fluorogenic AMC. The results showed that both $\mathrm{CuCl}$ and $\mathrm{CuCl}_{2}$ alone could inhibit the activity of purified $20 \mathrm{~S}$ proteasome (Fig. 3B). Again, $\mathrm{CuCl}$ is more potent than $\mathrm{CuCl}_{2}$. The data also showed that the proteasome-inhibitory ability of both $\mathrm{CuCl}$ and $\mathrm{CuCl}_{2}$ was significantly decreased when incubated with BCS (Fig. 3B). It indicates that direct binding of copper to proteasome may play a critical role in its proteasome-inhibitory activity since BCS is a copper ligand which could compete with the proteasome for binding with copper.

Both NC-copper complexes induce the production of ROS in breast cancer MDA-MB-231 cells, but $\mathrm{NC}-\mathrm{CuCl}-\mathrm{AH}$ is a much stronger ROS inducer. Production of ROS in cells is well known to be related to apoptotic cell death (20). A previous report demonstrated that copper and neocuproine complex induces apoptosis in astrocytes through oxidative stress and JNK activation (20). In the current study we found 
A

TBHP
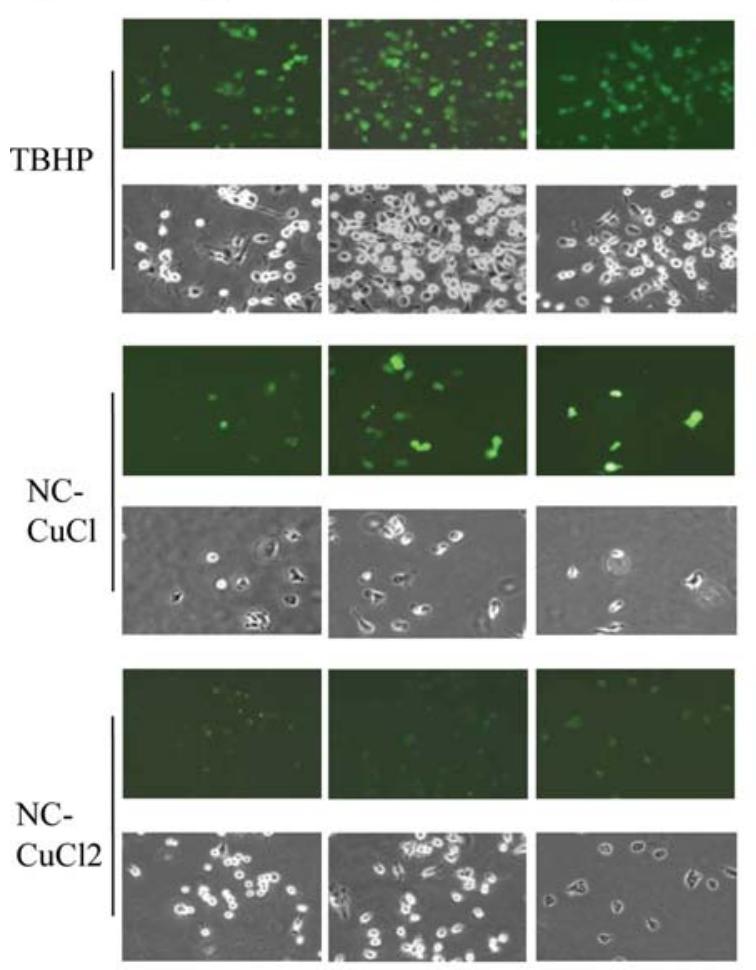

B

TBHP

Glu
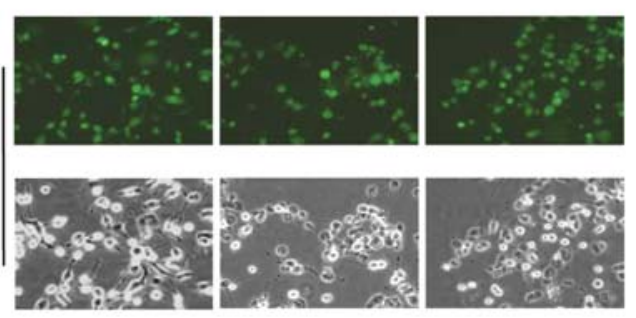

NC-
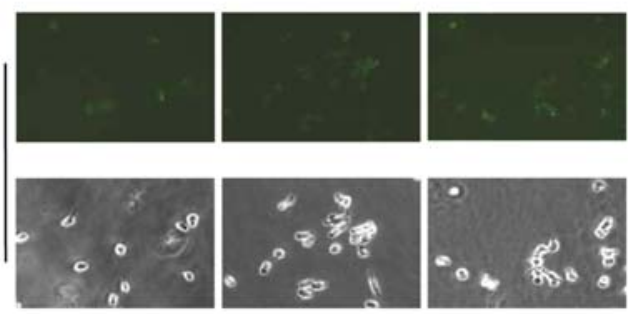

$\mathrm{CuCl}$

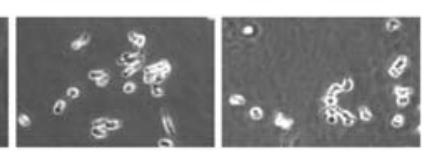

NC-
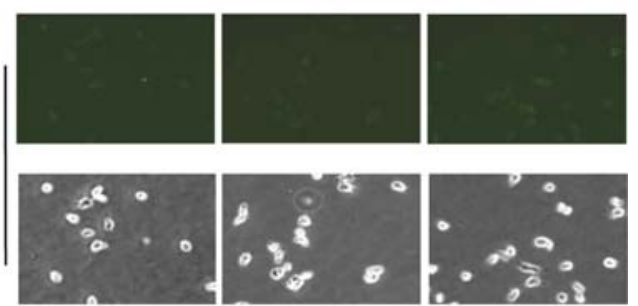

\section{C}

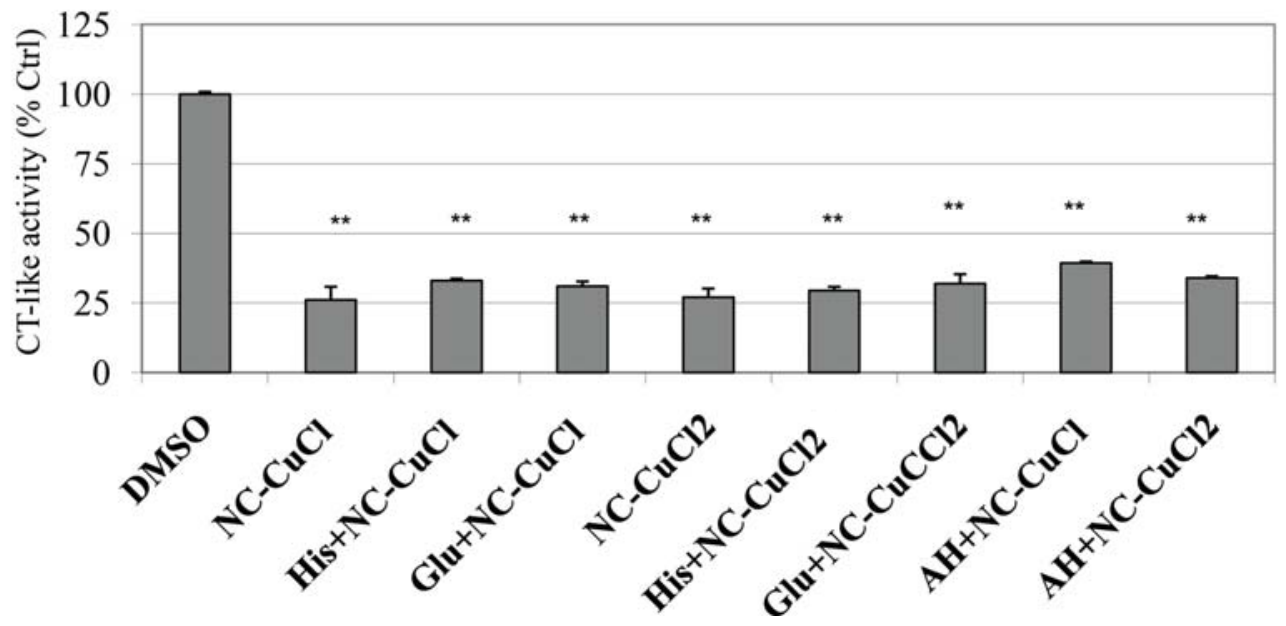

Figure 4. $\mathrm{NC}-\mathrm{CuCl}$ induces more ROS compared with $\mathrm{NC}-\mathrm{CuCl}_{2}$, and $\mathrm{ROS}$ scavengers are able to block ROS induction but can not overcome $\mathrm{NC}$-Cu-induced proteasome inhibition. (A) MDA-MB-231 cells were treated with $10 \mu \mathrm{M}$ of $\mathrm{NC}-\mathrm{AH}-\mathrm{CuCl}$ or $\mathrm{NC}^{-\mathrm{CuCl}_{2}}$ for 1,2 or $4 \mathrm{~h}$, followed by $\mathrm{ROS}$ stain (green color) assay and observed under fluorescence and phase contrast microscopy. Treatment with $200 \mu \mathrm{M}$ of TBHP for $1.5 \mathrm{~h}$ was used as positive control. (B) MDAMB-231 cells were pre-treated with $200 \mu \mathrm{M}$ of glutamine (Glu), histodine (His) or NAC for 30 min and post-treated with $10 \mu \mathrm{M}$ of NC-AH-CuCl or NC$\mathrm{CuCl}_{2}$ for $4 \mathrm{~h}$, followed by ROS stain assay and photography. Post-treatment with $200 \mu \mathrm{M}$ of TBHP for $1.5 \mathrm{~h}$ was used as positive control. Cellular morphological changes were visualized by phase-contrast imaging (magnification, x100). (C) Measurement of the proteasome chymotrypsin (CT)-like activity in aliquots of the cells treated for $4 \mathrm{~h}$ from above experiments in Fig. $4 \mathrm{~A}$ and $\mathrm{B} .{ }^{* *} \mathrm{P}<0.01$, bars, SD, mean of five experiments.

that $\mathrm{NC}$ and copper complexes induced apoptosis in MDAMB-231 cells (Fig. 2). In order to determine whether generation of ROS play a role in proteasome inhibition and cell death induction caused by $\mathrm{NC}-\mathrm{CuCl}$ and $\mathrm{NC}-\mathrm{CuCl}_{2}$, we used an Image-iT assay system that enables to detect ROS in live cells $(21,22)$. The ROS inducer TBHP was used as a positive control in this assy. The more ROS generates in cells, the more intensive fluorescent green will be visualized. In this study, MDA-MB-231 cells were treated with indi- cated concentrations of NC-CuCl-AH, $\mathrm{NC}-\mathrm{CuCl}_{2}$ or TBHP (positive control) for 1,2 or $4 \mathrm{~h}$. The results showed that both of the copper complexes were able to induce intracellular ROS production after $1 \mathrm{~h}$ of treatment (Fig. 4A). However, after 2 and $4 \mathrm{~h}$ of treatment much more ROS production was accumulated in the cells treated with $\mathrm{NC}-\mathrm{AH}-\mathrm{CuCl}$, compared with $\mathrm{NC}-\mathrm{CuCl}_{2}$ treatment (Fig. 4A). The results showed that $\mathrm{NC}-\mathrm{AH}-\mathrm{CuCl}$ was a much stronger $\mathrm{ROS}$ inducer than $\mathrm{NC}-\mathrm{CuCl}_{2}$. 
A
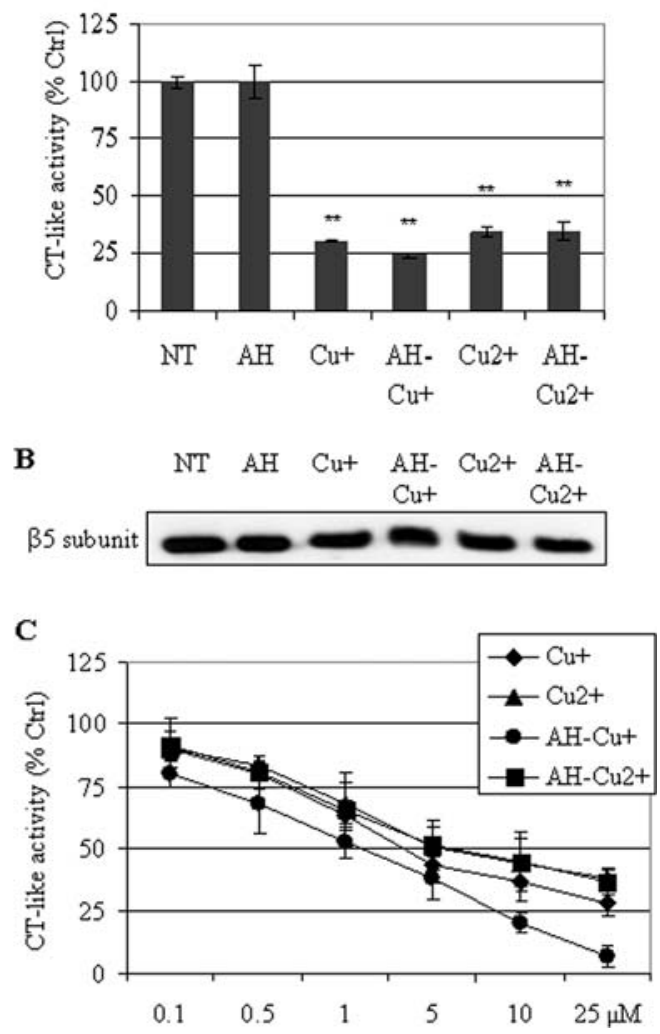

Figure 5. $\mathrm{Cu}(\mathrm{I})$ and $\mathrm{Cu}(\mathrm{II})$ inhibit the activity of purified $20 \mathrm{~S}$ proteasome probably by direct interaction. (A) The purified $20 \mathrm{~S}$ proteasome was incubated with $10 \mu \mathrm{M}$ of $\mathrm{CuCl}\left(\mathrm{Cu}^{+}\right)$or $\mathrm{CuCl}_{2}\left(\mathrm{Cu}^{2+}\right)$, or their mixtures with $\mathrm{AH}$ for overnight at $4^{\circ} \mathrm{C}$. After removing the unbound copper from the proteasome by multiple wash-spins in an Ultrafree-MC centrifugal filter unit (MW cut-off $10 \mathrm{kDa}$ ), $2 \mu \mathrm{l}$ of the $20 \mathrm{~S}$ proteasome solution from each sample was incubated with fluorogenic peptide substrates Suc-LLVY-AMC for $2 \mathrm{~h}$, followed by measurement of CT-like activity. (B) The amount of proteasome $B 5$ subunit in each sample was measured by Western blot analysis. (C) Purified 20S proteasome was pre-incubated with different concentrations of $\mathrm{Cu}(\mathrm{I}), \mathrm{Cu}(\mathrm{II})$ or their mixtures with $\mathrm{AH}$ for $4 \mathrm{~h}$ at $37^{\circ} \mathrm{C}$ and then post-incubated with fluorogenic peptide substrates Suc-LLVYAMC for $2 \mathrm{~h}$, followed by measurement of CT-like activity. ${ }^{* *} \mathrm{P}<0.01$, bars, $\mathrm{SD}$, mean of three experiments.

ROS scavengers block NC-copper-induced ROS generation in cancer cells, but can not inhibit the proteasome-inhibitory activity of the NC-copper complex. To investigate the relationship between accumulation of cellular ROS production and the proteasome inhibition induced by $\mathrm{NC}$-copper complexes, MDA-MB-231 cells were pre-treated with the ROS scavengers glutathione (Glu), histidine (His) or Nacetyl-L-cysteine (NAC) (23-25) for $30 \mathrm{~min}$, and then cotreated with $\mathrm{NC}-\mathrm{CuCl}-\mathrm{AH}$ or $\mathrm{NC}-\mathrm{CuCl}_{2}$ for $4 \mathrm{~h}$, followed by ROS image detection assay (Fig. 4B) and analysis of proteasome inhibition by the chymotrypsin-like activity assay (Fig. 4C). The results showed that either $\mathrm{Cu}(\mathrm{I})-$ or $\mathrm{Cu}(\mathrm{II})-$ induced ROS in the cells pretreated with Glu, His or NAC was almost completely eliminated (Fig. 4B), however these ROS scavengers could not overcome proteasome inhibition induced by $\mathrm{NC}-\mathrm{Cu}$ mixtures (Fig. 4C). Furthermore, these ROS scavengers did not reduce the cell death induced by NC-copper complexes (Fig. 4B). These findings indicated that the inhibition of proteasome activity by $\mathrm{NC}-\mathrm{Cu}$ mixtures might be mainly through copper-proteasome direct binding.
The cytotoxicity and apoptosis induced by $\mathrm{NC}-\mathrm{Cu}$ mixtures is associated with proteasome inhibition but not ROS induction.

Proteasome-inhibitory activity of $\mathrm{NC}-\mathrm{Cu}(\mathrm{I})$ may involve direct interaction with proteasome. We hypothesized that $\mathrm{Cu}(\mathrm{I})$-proteasome interaction may be responsible for the observed proteasome inhibition. To test this hypothesis, a purified human $20 \mathrm{~S}$ proteasome was pre-incubated with $\mathrm{CuCl}$ or $\mathrm{CuCl}_{2}$ for $12 \mathrm{~h}$. The free copper was removed by multiple wash-spins in an Ultrafree-MC centrifugal filter unit (MW cut-off $10 \mathrm{kDa}$ ). The $20 \mathrm{~S}$ proteasome solution from each sample was then incubated with fluorogenic peptide substrates Suc-LLVY-AMC for $2 \mathrm{~h}$, followed by measurement of proteasome activity. The data showed that both $\mathrm{CuCl}$ and $\mathrm{CuCl}_{2}$ could inhibit proteasome activity and consistently $\mathrm{Cu}(\mathrm{I})$ was more potent than $\mathrm{Cu}(\mathrm{II})$ (Fig. 5A). The results of Western blot in Fig. 5B confirmed that the amount of purified proteasome 35 protein in each sample was very similar. A similar experiment using different concentrations of $\mathrm{CuCl}$ or $\mathrm{CuCl}_{2}$ showed that direct inhibition of purified $20 \mathrm{~S}$ proteasome by $\mathrm{Cu}(\mathrm{I})$ or $\mathrm{Cu}$ (II) was dose-dependent (Fig. 5C).

\section{Discussion}

After revealing that copper is one of the pro-cancer factors and can boost angiogenesis in tumor tissue, scientists have tested whether reduction of copper level in cancer patients can present an anti-cancer effect. Results from clinical trials showed significant anti-angiogenic and antitumor effect of tetrathiomolybdate (TM), a copper-chelator, in the malignant pleural mesothelioma and the advanced kidney cancer patients $(26,27)$. Our group has examined a series of copperbinding compounds and tested their antitumor activity. We found that among these compounds disulfiram and clioquinol possess proteasome-inhibitory and apoptosis-inducing properties when they are mixed with copper $(10,14)$. We also examined tumor tissue from mice by X-ray fluorescence microscopy and found that $\mathrm{Cu}(\mathrm{I})$ was predominant in the growing tumor tissue while increased $\mathrm{Cu}$ (II) was found in tumors treated with clioquinol (28). Therefore, a new question has been raised: which oxidation states of copper have anti-tumor activity when reacted with a copper ligand.

In the current study we mixed neocuproine (NC) a copper ligand with $\mathrm{CuCl}$ or $\mathrm{CuCl}_{2}$. We also used ascorbic acid (AH) as a reducer in $\mathrm{NC}-\mathrm{CuCl}$ mixture to protect $\mathrm{Cu}(\mathrm{I})$ from oxidation. First, we tested $\mathrm{NC}-\mathrm{Cu}(\mathrm{I})$ and $\mathrm{NC}-\mathrm{Cu}(\mathrm{II})$ for their proteasome-inhibitory property. In the in vitro assay by using purified 20S proteasome we found that both copper mixtures inhibited proteasome activity and $\mathrm{NC}-\mathrm{Cu}(\mathrm{I})$ was slightly more potent than $\mathrm{NC}-\mathrm{Cu}(\mathrm{II})$. We further tested the proteasomal-inhibitory effect of both mixtures on cultured human breast cancer cells and the results were consistent with the findings in vitro. It has been reported that the majority of copper in cells and tissues is $\mathrm{Cu}(\mathrm{I})$ and that copper is reduced to $\mathrm{Cu}(\mathrm{I})$, when transported into a cell, by the copper transporter on cell membrane (29).

Generation of ROS and its involvement in induction of various cancer cell apoptosis has been well investigated $(6,30)$. We hypothesized that $\mathrm{Cu}(\mathrm{I})$ and $\mathrm{Cu}(\mathrm{II})$ may have different effects on ROS generation and thereby on cell 
apoptosis. Our findings showed that indeed $\mathrm{NC}-\mathrm{Cu}(\mathrm{I})$ was a potent ROS inducer, compared with $\mathrm{NC}-\mathrm{Cu}(\mathrm{II})$. However, the generation of ROS by $\mathrm{NC}-\mathrm{Cu}(\mathrm{I})$ was not needed for its proteasome-inhibitory activity since ROS scavengers could block ROS generation produced by $\mathrm{NC}-\mathrm{Cu}(\mathrm{I})$ but could not overcome its proteasomal-inhibitory activity. One of the possible mechanisms for $\mathrm{NC}-\mathrm{Cu}(\mathrm{I})$ to inhibit proteasome activity may be direct binding of $\mathrm{Cu}(\mathrm{I})$ to the active site of proteasome B5 subunit. Further experiments are needed to confirm whether ROS is involved in the cell death induced by copper complexes.

In summary, we have provided evidence that trace metal copper in different oxidation states have different biological effects in cancer cells. Copper plays an important role as procancer factor in tumor tissues especially in tumor angiogenesis and metastasis. Our findings demonstrated that when complexed with a copper ligand, copper preferentially in its reduced status could be converted to a proteasome inhibitor and an apoptosis inducer. The findings not only help us to further understand the biological effects of copper in different oxidation/reduction states in cells, but also provide a rationale for synthesis of copper-containing complexes as potential anticancer reagents.

\section{Acknowledgements}

This research is partially supported by Karmanos Cancer Institute of Wayne State University (to Q.P. Dou), National Cancer Institute/NIH (1R01CA120009, 3R01CA12000904S1, and 1R21CA139386 to Q.P. Dou), and the National Cancer Institute/NIH Cancer Center Support Grant (to Karmanos Cancer Institute). This research was also partially supported by a Scholarship from the Chinese Scholarship Council (to Y. Xiao and X. Zhang). We thank Ms. Carol Maconochie for critical reading of the manuscript.

\section{References}

1. Aggett PJ and Fairweather-Tait S: Adaptation to high and low copper intakes: its relevance to estimated safe and adequate daily dietary intakes. Am J Clin Nutr 67: S1061-S1063, 1998.

2. Labbe S and Thiele DJ: Pipes and wiring: the regulation of copper uptake and distribution in yeast. Trends Microbiol 7: 500-505, 1999

3. Fox SB, Gasparini G and Harris AL: Angiogenesis: pathological, prognostic, and growth-factor pathways and their link to trial design and anticancer drugs. Lancet Oncol 2: 278-289, 2001.

4. Gourley M and Williamson JS: Angiogenesis: new targets for the development of anticancer chemotherapies. Curr Pharm Des 6: 417-439, 2000.

5. Ryan CJ and Wilding G: Angiogenesis inhibitors. New agents in cancer therapy. Drugs Aging 17: 249-255, 2000.

6. Huang YL, Sheu JY and Lin TH: Association between oxidative stress and changes of trace elements in patients with breast cancer. Clin Biochem 32: 131-136, 1999.

7. Nayak SB, Bhat VR, Upadhyay D and Udupa SL: Copper and ceruloplasmin status in serum of prostate and colon cancer patients. Indian J Physiol Pharmacol 47: 108-110, 2003.

8. Rizk SL and Sky-Peck HH: Comparison between concentrations of trace elements in normal and neoplastic human breast tissue. Cancer Res 44: 5390-5394, 1984.

9. Turecky L, Kalina P, Uhlikova E, Namerova S and Krizko J: Serum ceruloplasmin and copper levels in patients with primary brain tumors. Klin Wochenschr 62: 187-189, 1984.

10. Chen D, Cui QC, Yang H and Dou QP: Disulfiram, a clinically used anti-alcoholism drug and copper-binding agent, induces apoptotic cell death in breast cancer cultures and xenografts via inhibition of the proteasome activity. Cancer Res 66: 10425-10433, 2006.
11. Chen D, Peng F, Cui QC, et al: Inhibition of prostate cancer cellular proteasome activity by a pyrrolidine dithiocarbamatecopper complex is associated with suppression of proliferation and induction of apoptosis. Front Biosci 10: 2932-2939, 2005.

12. Daniel KG, Chen D, Orlu S, Cui QC, Miller FR and Dou QP: Clioquinol and pyrrolidine dithiocarbamate complex with copper to form proteasome inhibitors and apoptosis inducers in human breast cancer cells. Breast Cancer Res 7: R897-R908, 2005.

13. Daniel KG, Gupta P, Harbach RH, Guida WC and Dou QP: Organic copper complexes as a new class of proteasome inhibitors and apoptosis inducers in human cancer cells. Biochem Pharmacol 67: 1139-1151, 2004.

14. Rahman A, Shahabuddin, Hadi SM, Parish JH and Ainley K: Strand scission in DNA induced by quercetin and $\mathrm{Cu}(\mathrm{II})$ : role of $\mathrm{Cu}(\mathrm{I})$ and oxygen free radicals. Carcinogenesis 10: 1833-1839, 1989.

15. Chen D, Cui QC, Yang H, et al: Clioquinol, a therapeutic agent for Alzheimer's disease, has proteasome-inhibitory, androgen receptor-suppressing, apoptosis-inducing, and antitumor activities in human prostate cancer cells and xenografts. Cancer Res 67: 1636-1644, 2007.

16. Zhu BZ and Chevion M: Copper-mediated toxicity of 2,4,5trichlorophenol: biphasic effect of the copper(I)-specific chelator neocuproine. Arch Biochem Biophys 380: 267-273, 2000.

17. Bhat SH, Azmi AS, Hanif S and Hadi SM: Ascorbic acid mobilizes endogenous copper in human peripheral lymphocytes leading to oxidative DNA breakage: a putative mechanism for anticancer properties. Int J Biochem Cell Biol 38: 2074-2081, 2006.

18. An B, Goldfarb RH, Siman R and Dou QP: Novel dipeptidyl proteasome inhibitors overcome $\mathrm{Bcl}-2$ protective function and selectively accumulate the cyclin-dependent kinase inhibitor p27 and induce apoptosis in transformed, but not normal, human fibroblasts. Cell Death Differ 5: 1062-1075, 1998.

19. Lopes UG, Erhardt P, Yao R and Cooper GM: p53-dependent induction of apoptosis by proteasome inhibitors. J Biol Chem 272: 12893-12896, 1997.

20. Chen SH, Lin JK, Liu SH, Liang YC and Lin-Shiau SY: Apoptosis of cultured astrocytes induced by the copper and neocuproine complex through oxidative stress and JNK activation. Toxicol Sci 102: 138-149, 2008.

21. Khanna S, Roy S, Parinandi NL, Maurer M and Sen CK: Characterization of the potent neuroprotective properties of the natural vitamin E alpha-tocotrienol. J Neurochem 98: 1474-1486, 2006.

22. Kim JK, Pedram A, Razandi M and Levin ER: Estrogen prevents cardiomyocyte apoptosis through inhibition of reactive oxygen species and differential regulation of p38 kinase isoforms. J Biol Chem 281: 6760-6767, 2006.

23. Kawamoto T, Ikeda Y and Teramoto A: [Protective effect of Lhistidine (singlet oxygen scavenger) on transient forebrain ischemia in the rat]. No To Shinkei 49: 612-618, 1997.

24. Lawton DG, Gorman C and Lowe PN: Small G protein characterisation by isothermal titration calorimetry. Biochem Soc Trans 25: S510, 1997.

25. Rattan AK and Arad Y: Temporal and kinetic determinants of the inhibition of LDL oxidation by $\mathrm{N}$-acetylcysteine (NAC). Atherosclerosis 138: 319-327, 1998.

26. Pass HI, Brewer GJ, Dick R, Carbone M and Merajver S: A phase II trial of tetrathiomolybdate after surgery for malignant mesothelioma: final results. Ann Thorac Surg 86: 383-389; discussion 390, 2008

27. Redman BG, Esper P, Pan Q, et al: Phase II trial of tetrathiomolybdate in patients with advanced kidney cancer. Clin Cancer Res 9: 1666-1672, 2003.

28. Barrea RA, Chen D, Irving TC and Dou QP: Synchrotron X-ray imaging reveals a correlation of tumor copper speciation with Clioquinol's anticancer activity. J Cell Biochem 108: 96-105, 2009.

29. Ohgami RS, Campagna DR, McDonald A and Fleming MD: The Steap proteins are metalloreductases. Blood 108: 1388-1394, 2006.

30. Izeradjene K, Douglas L, Tillman DM, Delaney AB and Houghton JA: Reactive oxygen species regulate caspase activation in tumor necrosis factor-related apoptosis-inducing ligandresistant human colon carcinoma cell lines. Cancer Res 65 : 7436-7445, 2005 